\title{
Marcel Proust, «Le Mensuel» retrouvé
}

\section{Geneviève Henrot Sostero}

\section{(2) OpenEdition}

\section{Journals}

\section{Édition électronique}

URL : http://journals.openedition.org/studifrancesi/2257

DOI : 10.4000/studifrancesi.2257

ISSN : 2427-5856

\section{Éditeur}

Rosenberg \& Sellier

\section{Édition imprimée}

Date de publication : 1 avril 2014

Pagination : 179

ISSN : 0039-2944

\section{Référence électronique}

Geneviève Henrot Sostero, "Marcel Proust, «Le Mensuel» retrouvé », Studi Francesi [En ligne], 172 (LVIII I I) | 2014, mis en ligne le 01 avril 2014, consulté le 18 septembre 2020. URL : http://

journals.openedition.org/studifrancesi/2257 ; DOI : https://doi.org/10.4000/studifrancesi.2257

Ce document a été généré automatiquement le 18 septembre 2020.

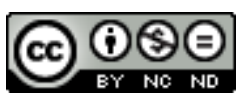

Studi Francesi è distribuita con Licenza Creative Commons Attribuzione - Non commerciale - Non opere derivate 4.0 Internazionale. 


\title{
Marcel Proust, «Le Mensuel» retrouvé
}

\author{
Geneviève Henrot Sostero
}

\section{RÉFÉRENCE}

MARCEL PROUST, «Le Mensuel» retrouvé, précédé de Jérôme PRIEUR, Marcel avant Proust, Éditions des Busclats, 2012, pp. 140.

1 La collection qui accueille ce savoureux petit volume a pour vocation d'explorer les marges d'une grande œuvre, ces "pas de côté" qui dévoilent l'un ou l'autre coin secret d'un imaginaire par ailleurs censé bien arpenté.

2 C'est ce que fait Jérôme Prieur, qui n'en est pas à son premier écrit sur Proust, puisqu'on lui doit déjà Séance de lanterne magique (Gallimard, «Le Chemin», 1985), Petit tombeau de Marcel Proust (Éditions La Pionnière, 2000), et Proust fantôme, (Le Promeneur, 2011; «Folio» 4412, 2006). Cet écrivain et cinéaste se penche sur le jeune Marcel et traque les débuts (quasi) anonymes de l'écrivain dans la revue fondée et gérée par son condisciple Otto Bouwens Van der Boijin: «Le Mensuel». «Marcel avant Proust», le lycéen, l'étudiant, fut tôt pris de la fureur de publier: des «Impressions des salons», des articles de mode féminine, des variétés apparaissent dans «Le Mensuel» avant de se destiner au «Banquet». Proust y exerce précocement son esprit critique, son ironie subtile, son esprit d'observation, son goût du beau, son attirance pour le monde, son opinion déjà ferme en matière de poésie et de peinture.

3 Jérôme Prieur traque et retrace les quelques rares éléments concernant la collaboration de Proust à l'éphémère revue, et commente avec verve les relations d'amitié et d'hostilité qui y transparaissent. Il introduit ainsi de façon piquante le recueil de petits textes que Proust a confiés à la revue: le style alerte, humoriste, enlevé qui s'y aiguise fait découvrir un Proust échotier et primesautier auquel il ne faisait pas bon se frotter. 